\title{
PENGARUH KEPEMIMPINAN DAN KOMPETENSI APARATUR TERHADAP KUALITAS PELAYANAN PUBLIK
}

\author{
Asep Setiadi ${ }^{1}$ \\ ${ }^{1}$ Program Studi Manajemen Pascasarjana Universitas Galuh Ciamis \\ email: asepsetiadi090@gmail.com
}

\section{Article History : \\ Received 4February 2018 \\ Recieved in revished form \\ 18 February 2018 \\ Acepted 4May 2018 \\ Available offline 20 May 2018 \\ Available online 20 May 2018}

\section{Language Transcript : \\ Indonesia}

Key Words :

Kepemimpinan

Kompetensi Aparatur

Kualitas Pelayanan Publik

\begin{abstract}
Tujuan dari artikel ini adalah untuk melihat pengaruh kepemimpinan dan kompetensi aparatur terhadap kualitas pelayanan publik. Metode yang digunakan adalah metode penelitian deskriptif kuantitatif. Hasil penelitian yang diperoleh adalah sebagai berikut: Kepemimpinan berpengaruh terhadap kualitas pelayanan publik pada Badan Keluarga Berencana dan Pemberdayaan Perempuan Kota Banjar dengan kategori sedang. Hal ini menunjukkan bahwa kepemimpinan berpengaruh sedang terhadap kualitas pelayanan public. Semakin baik kepemimpinan maka akan semakin baik kualitas pelayanan publik pada Badan Keluarga Berencana dan Pemberdayaan Perempuan Kota Banjar; Kompetensi aparatur berpengaruh terhadap kualitas pelayanan publik pada Badan Keluarga Berencana dan Pemberdayaan Perempuan Kota Banjar dengan kategori sedang. Hal ini menunjukkan bahwa Kompetensi aparatur berpengaruh sedang terhadap kualitas pelayanan public. Semakin baik Kompetensi aparatur maka akan semakin baik kualitas pelayanan publik pada Badan Keluarga Berencana dan Pemberdayaan Perempuan Kota Banjar; Kepemimpinan dan kompetensi aparatur berpengaruh terhadap kualitas pelayanan publik pada Badan Keluarga Berencana dan Pemberdayaan Perempuan Kota Banjar dengan kategori sangat baik. Hal ini menunjukkan bahwa Kepemimpinan dan kompetensi aparatur berpengaruh sangat baik terhadap kualitas pelayanan public. Semakin baik Kepemimpinan dan kompetensi aparatur maka akan semakin baik kualitas pelayanan publik pada Badan Keluarga Berencana dan Pemberdayaan Perempuan Kota Banjar.
\end{abstract}

\section{PENDAHULUAN}

Dalam menghadapi era globalisasi yangpenuh tantangan dan peluang,aparatur Negara dalam hal ini dititikberatkan kepada aparatur pemerintahanhendaknya memberikan pelayanan yang sebaikbaiknya, berorientasi padakebutuhan dan kepuasan penerima pelayanan, sehingga dapat meningkatkandaya saing dalam pemberi pelayanan barang dan jasa. $\begin{array}{lrr}\text { Permintaan } & \text { pelayanan } & \text { publik terus } \\ \text { meningkat } & \text { baik } & \text { kuantitas }\end{array}$ maupunkualitasnya. Hal tersebut terkait dengan semakin meningkatnya jumlah penduduk, meningkatnya tingkat pendidikan, meningkatnya kebutuhan, semakin beragambya lapangan pekerjaan dan semakin bertambahnya tingkat kesejahteraan masyarakat. Pelayanan publik bukan hanya merupakan persoalanadministratif saja tetapi lebih tinggi dari itu yaitu pemenuhan keinginan 
daripublik. Oleh karena itu diperlukan kesiapan bagi adminitator pelayan publik agardapat dicapai kualitas pelayanan yang baik. (Sumartono, 2007:90)

Berlakunya UU Nomor 22 Tahun 1999 yang disempurnakan menjadi UUNomor 32 Tahun 2004 tentang Pemerintahan Daerah dan UU Nomor 25 Tahun1999 yang juga disempurnakan menjadi UU Nomor 33 Tahun 2004 TentangPerimbangan Keuangan Antara Pemerintah Pusat dan Pemerintah Daerah, makapemerintah daerah di harapkan memberikan dampak nyata yang luas terhadappeningkatan pelayanan terhadap masyarakat. Pelimpahan wewenang dariPemerintah Pusat ke Daerah memungkinkan terjadinya penyelenggaraanpelayanan dengan jalur birokrasi yang lebih ringkas dan membuka peluang bagiPemerintah Daerah untuk melakukan inovasi dalam pemberian dan peningkatankualitas pelayanan.

Pelayanan sebagai proses pemenuhan kebutuhan melalui aktivitas orang lain secara langsung, merupakan konsep yang senantiasa aktual dalam berbagai aspek kelembagaan. Bukan hanya pada organisasi bisnis, tetapi telah berkembang lebih luas pada tatanan organisasi pemerintah (Sinambela, 2006:42-43).

Dewasa ini kehidupan masyarakat mengalami banyak perubahan sebagai akibat dari kemajuan yang telah dicapai dalam proses pembangunan sebelumnya dan kemajuan yang pesat dalam ilmu pengetahuan dan teknologi. Perubahan yang dapat dirasakan sekarang ini adalah terjadinya perubahan pola pikir masyarakat ke arah yang semakin kritis. Hal itu dimungkinkan, karena semakin hari warga masyarakat semakin cerdas dan semakin memahami hak dan kewajibannya sebagai warga.

Kondisi masyarakat yang demikian menuntut hadirnya pemerintah yang mampu memenuhi berbagai tuntutan kebutuhan dalam segala aspek kehidupan mereka, terutama dalam mendapatkan pelayanan yang sebaik-baiknya dari pemerintah. Dalam kaitannya itu (Rasyid 1997:11) mengemukakan bahwa : Pemerintah modern, dengan kata lain, pada hakekatnya adalah pelayanan kepada masyarakat. Pemerintah tidaklah diadakan untuk melayani dirinya sendiri, tetapi untuk melayani masyarakat. Memungkinkan setiap anggota masyarakat mengembangkan kemampuan dan kreativitasnya demi mencapai kemajuan bersama.

Pemberian palayanan yang memenuhi standar yang telah ditetapkan memang menjadi bagian yang perlu dicermati. Saat ini masih sering dirasakan bahwa kualitas pelayanan minimum sekalipun masih jauh dari harapan masyarakat. Yang lebih memprihatinkan lagi, masyarakat hampir sama sekali tidak memahami secara pasti tentang pelayanan yang seharusnya diterima dan sesuai dengan prosedur pelayanan yang baku oleh pemerintah.

Masyarakatpun enggan mengadukan apabila menerima pelayanan yang buruk, bahkan hampir pasti mereka pasrah menerima layanan seadanya. Kenyataan semacam ini terdorong oleh sifatpublic goods menjadi monopoli pemerintah khususnya dinas/instansi pemerintah daerah dan hampir tidak ada pembanding dari pihak lain. Praktek semacam ini menciptakan kondisi yang merendahkan posisi tawar dari masyarakat sebagai penggunan jasa pelayanan dari pemerintah, sehingga memaksa masyarakat mau tidak mau menerima dan menikmati pelayanan yang kurang memadai tanpa protes.

Hasil studi pendahuluan pada Badan Keluarga berencana dan Pem,berdayaan Perempuan Kota Banjar diketahui bahwa Badan Keluarga Berencana dan Pemberdayaan Perempuan sebagai salah satu lembaga pemerintah yang secara resemi memiliki tugas dan fokok membantu Bupati dalam menyelenggarakan 
kewenangan Pemerintah Kabupaten di bidang perencanaan, penelitian dan pengkajian, pengolahan data, pembinaan dan pengembangan, pemantauan dan evaluasi kegiatan keluarga berncana dn pemberdayaan perempuan serta pelaksanaan urusan ketatausahaan Badan. Namun kenyataan dilapangan bahwa pelayanan yang diberikan oleh Badan Keluarga berencana dan Pem,berdayaan Perempuan Kota Banjar masih belum maksimal.

Sejak diberlakukan penyelenggaraan otonomi daerah, penyerahan, pelimpahan dan penugasan urusan pemerintah kepada daerah secara nyata dan bertanggung jawab harus diikuti dengan pengaturan, pembagian dan pemanfaatan sumber daya nasional secara adil, termasuk pertimbangan keuangan antara pemerintah dan pemerintah daerah. Sebagai daerah otonom, penyelenggara pemerintah dan pelayanan tersebut dilakukan berdasarkan prinsip-prinsip transparansi, partisipasi dan akuntabilitas. Sebagaimana yang diamanatkan oleh Undang-undang No. 25 Tahun 2009 tentang Pelayanan Publik, bahwa : "Pelayanan publik harus melayani masyarakat secara maksimal". Pelayanan publik yang dilakukan oleh pemerintah, sangat bergantung kepada pelaksana pelayanan publik itu sendiri.

Dalam hal agar terciptanya pelayanan publik yang baik dan memuaskan bagi masyarakat tentunya diperlukan kompetensi dan kepemimpinan yang baik pula dari pihak penyelenggara pelayanan tersebut. Sebagai karakteristik dasar, kompetensi merupakan bagian dari kepribadian individu yang relatif dalam dan stabil, dapat dilihat dan diukur dari perilaku individu yang bersangkutan di tempat kerja atau dalam berbagai situasi. Untuk itu kompetensi seseorang mengindikasikan kemampuan berperilaku seseorang dalam berbagai situasi yang cukup konsisten untuk suatu periode waktu yang cukup panjang dan bukan hal yang kebetulan semata. Kompetensi dapat digunakan untuk menduga atau terbukti secara empiris merupakan penyebab suatu keberhasilan perilaku atau kinerja yang secara akademis didasarkan pada kriteria ukuran keberhasilan sebagai standar kinerja yang dapat diterima secara bisnis maupun sosial.

Pelayanan publik yang berkualitas atau pelayanan prima dapat dilakukan dengan baik manakala didukung oleh kinerja yang baik dan berkualitas dari pegawai. Pegawai dikatakan memiliki kinerja yang baik apabila mampu melaksanakan pekerjaannya dengan baik dan sesuai target yang direncanakan. Untuk itu pegawai dituntut memiliki kualitas sumber daya pegawai yang baik dan berkompoten dibidangnya. Seperti yang dikemukakan oleh Armstrong (1998: 55), bahwa kompetensi adalah knowledge, skill dan kualitas individu untuk mencapai kesuksesan pekerjaannya. Oleh karena itu sangat diperlukan pengetahuan dan keterampilan yang berkualitas dalam meningkatkan kinerjanya.

Dari pernyataan tersebut di atas, bahwa kompetensi merupakan salah satu faktor yang membedakan seseorang yang mampu menunjukkan kinerja yang optimal dengan seseorang yang tidak mampu menunjukan kinerja yang optimal. Kompetensi merupakan kumpulan sumber daya manusia yang secara dinamis menunjukkan kapasitas intelektual, kualitas sikap mental dan kapabilitas sosial seseorang. Disisi lain kreativitas para pegawai dan pemimpin sangat menentukan dalam keberhasilan organisasi (Herlina et.al. 2018).

Peran kepemimpinan dalam efektivitas pencapaian tujuan dapat dilakukan dengan melakukan upaya-upaya memberikan bimbingan dan pengarahan sehingga dapat meningkatkan kompetensi dan bertanggung jawab terhadap perkembangan kehidupan bersama dan mampu mengakomodasi aspirasi masyarakat. Menurut Bubshait and Farooq (2011:45), kepemimpinan berada 
dibelakang setiap keberhasilan program yang dijalankan oleh tim, dan kepemimpinan harus mampu mengawali dan mengarahkan tim dari atas. Pemimpin tim (team leaders) yang berhasil dengan sendirinya akan mengetahui bahwa hasil yang diperoleh oleh timnya merupakan sesuatu yang penting, bukan karena hasil individu dari kerja kerasnya sendiri atau hasil dari anggotanya, tetapi karena kerjasama antara anggota tim dan pemimpinnya. Pemimpin sebuah tim proyek ada dua, yaitu pemimpin formal dan pemimpin informal.

Penyelenggaraan pemerintahan, pembangunan dan pelayanan publik yang dilakukan oleh pemerintah atau pemerintah daerah, selama ini didasarkan pada paradigma rule government (pendekatan legalitas). Dalam merumuskan, menyusun dan menetapkan kebijakan senantiasa didasarkan pada pendekatan prosedur dan keluaran (output), serta dalam prosesnya menyandarkan atau berlindung pada peraturan perundangundangan atau mendasarkan pada pendekatan legalitas. Penggunan paradigma rule government atau pendekatan legalitas, dewasa ini cenderung mengedepankan prosedur, hak dan kewenanganatas urusan yang dimiliki (kepentingan pemerintah daerah), dan kurangmemperhatikan prosesnya. Pengertiannya, dalam proses merumuskan, menyusundan menetapkan kebijakan, kurang optimal melibatkan stakeholders (pemangkukepentingan di lingkungan birokrasi, maupun masyarakat).

Penyelenggaraan

pemerintahan,pembangunan dan pelayanan publikmenurut paradigma good governance, dalam prosesnya tidak hanya dilakukanoleh pemerintah daerah berdasarkan pendekatan rule government (legalitas), atauhanya untuk kepentingan pemerintahan daerah. Paradigma good governance, mengedepankan proses dan prosedur, dimana dalam proses persiapan, perencanaan, perumusan dan penyusunan suatu kebijakan senantiasa mengedepankan kebersamaan dan dilakukan dengan melibatkan seluruhpemangku kepentingan.

Dikaitkan dengan otonomi daerah sebenarnya hal ini merupakan peluang baik bagi daerah untuk menunjukan kinerjanya untuk meningkatkan kesejahteraan masyarakat di wilayahnya, termasuk upaya menuju pewujudan good local governance mapan. Kualitas pelayanan publik di daerah masih perlu ditingkatkan ke arah yang lebih baik. Masyarakat di daerah mempunyai tuntutan yang lebih untuk mendapatkan pelayanan yang optimal demi kepuasan pelayanan yang diterima dari penyelenggara. Setiap instansi pemerintah dituntut untuk dapat memberikan pelayanan publik yang terbaik kepada masyarakat termasuk salah satu bentuk intansi pemerintah adalah Badan Keluarga Berencana dan Pemberdayaan Perempuan.

Berdasarkan Peraturan Pemerintah Nomor 41 tahun 2007 tentang Pedoman Organisasi Perangkat Daerah, maka secara teknis yang menangani Urusan Keluarga Berencana dan Keluarga Sejahtera dilaksanakan oleh Badan Keluarga Berencana dan Pemberdayaan Perempuan sesuai dengan Peraturan Daerah Kota Banjar No.06 tahun 2010 atas perubahan Perda. No. 11 tahun 2008 tentang OPD, Badan Keluarga Berencana dan Pemberdayaan Perempuan Kota Banjar adalah salah satu instansi yang merupakan unsur penunjang Pemerintah Daerah yang bertugas menangani Program Pemberdayaan Perempuan dan Program Keluarga Berencana. Program Keluarga Berencana merupakan salah satu program sosial dasar yang sangat penting artinya bagi kemajuan suatu bangsa. Program ini memberikan kontribusi yang besar bagi pembangunan sumber daya manusia pada masa kini dan masa yang akan datang, yang menjadi prasyarat bagi kemajuan dan kemandirian bangsa, oleh karena itu 
pegawai Badan Keluarga Berencana dan Pemberdayaan Perempuan Kota Banjar dituntut mampu memberikan pelayanan kepada masyarakat secara optimal dengan cara memaksimalkan kinerja.Kondisi pegawai yang ada saat ini pada Badan Keluarga Berencana dan Pemberdayaan Perempuan Kota Banjar dijumpai masih adanya pegawai bersikap pasif terhadap pekerjaan, adanya pegawai yang tidak tepat waktu dalam menyelesaikan pekerjaannya dan masih adanya sebagian pegawai yang produktivitas kerjanya belum optimal. Dengan demikian organisasi kiranya perlu untuk menciptakan suatu kondisi yang dapat memberikan dorongan bagi pegawai, mengingat bahwa kepemimpinan dan kompetensi dimaksud belum optimal dalam mencapai kinerja pelayanan .yang diharapkan.

Untuk dapat menentukan berhasil atau tidaknya peningkatan pelayanan sangat tergantung pada manusianya juga, untuk meningkatkan pelayanan diperlukan pengembangan tugas yang mempunyai disiplin mental dan fisik yang baik. Dengan pengaturan yang harmonis antara manusia, materiil dan keuangan, diharapakan dapat mencapai hasil yang optimal dalam pelayanan. Oleh sebab itu kualitas pelayanan perlu ditingkatkan dan diperbaiki, khususnya kemampuan pegawai untuk dapat bekerja dengan optimal dalam pemberian pelayanan terhadap masyarakat.

Persoalan kinerja pelayanan publik menjadi persoalan yang sering dibahas diberbagai instansi pemerintah, demikian halnya dengan Badan Keluarga Berencana dan Pemberdayaan Perempuan Kota Banjar, sebagai instansi yang bergerak di bidang pengawasan dan pembinaan baik kepada pegawai negeri juga kepada masyarakat, pegawainya dituntut untuk memberikan kinerja yang baik dalam rangka memberikan pelayanan publik yang berkualitas, pelayanan ini seperti peran aktif pegawai dalam pencegahan dini penanggulangan korban bencana alam dengan cara melakukan pemantauan dan penyebarluasan informasi potensi bencana alam, hal ini secara tidak langsung telah membantu masyarakat dalam mengurangi kekhawatiran mereka pada saat terjadinya bencana. Tetapi harapan ini belum sesuai dengan harapan dan keinginan serta kebutuhan masyarakat hingga saat ini. Berdasarkan observasi awal yang dilakukan peneliti di lapangan, mendapatkan informasi bahwapelaksanaan pelayanan pemberdayaan masyarakat pada Badan Keluarga Berencana dan Pemberdayaan Perempuan Kota Banjar masih belum optimal , dimana masih adanya beberapa program kerja pengembangan pemberdayaan masyarakat yang telah direncanakan belum tersealisasikan.

Berdasarkan uraian tersebut peneliti tertarik melakukan penelitian lebih mendalam dengan mengambil judul : "Pengaruh Kepemimpinan dan Kompetensi Aparatur terhadap Kualitas Pelayanan Publik".

\section{METODOLOGI}

Metode adalah cara yang digunakan. Berkaitan dengan penelitian ini digunakan salah satu metode yang di pandang tepat untuk memproses masalah yang dikemukakan. Metode yang dimaksud, adalah metode deskriptif.

\section{HASIL DAN PEMBAHASAN}

\subsection{Analisis Pengaruh Kepemimpinan Terhadap Kualitas Pelayanan Publik}

Kepemimpinan berpengaruh terhadap kualitas pelayanan publik pada Badan Keluarga Berencana dan Pemberdayaan Perempuan Kota Banjar dengan kategori sedang. Hal ini menunjukkan bahwa kepemimpinan berpengaruh sedang terhadap kualitas pelayanan public. Semakin baik kepemimpinan maka akan semakin baik kualitas pelayanan publik 
pada Badan Keluarga Berencana dan Pemberdayaan Perempuan Kota Banjar.

Kepemimpinan telah didefinisikan sebagai proses mempengaruhi aktivitas seseorang atau kelompok untuk mencapai tujuan dalam situasi tertentu. Dalam esensinya, kepemimpinan merupakan upaya pencapaian tujuan dengan dan melalui orang-orang. Berdasarkan pendapat diatas dapat disimpulkan bahwa kepemimpinan adalah kemampuan mempengaruhi bawahan atau kelompok untuk bekerja sama mencapai tujuan organisasi atau kelompok.

Pemimpin dalam suatu organisasi atau instansi memiliki gaya atau tipe kepemimpinan yang berbeda-beda. Masingmasing gaya atau tipe kepemimpinan dapat dipastikan akan mengakibatkan dampak yang berbeda kepada para pegawai atau bawahannya. Namun, yang patut diperhatikan oleh setiap pemimpin adalah gaya atau tipe kepemimpinannya harus dapat memajukan organisasi atau instansi yang dipimpinnya, bukan sebaliknya. Kepemimpinan merupakan salah satu faktor yang sangat penting dalam suatu organisai karena sebagian besar keberhasilan dan kegagalan suatu organisasi ditentukan oleh kepemimpinan dalam organisasi tersebut.

Menurut Young, 2012, Pengertian kepemimpinan yaitu bentuk dominasi yang didasari atas kemampuan pribadi yang sanggup mendorong atau mengajak orang lain untuk berbuat sesuatu yang berdasarkan penerimaan oleh kelompoknya. Defenisi Young tersebut mencakup tiga elemen berikut:

1. Kepemimpinan merupakan suatu konsep relasi (relational concept). Kepemimpinan hanya ada dalam proses relasi dengan orang lain (pengikut). Apabila tidak ada pengikut, maka tidak ada pemimpin.
2. Kepemimpinan merupakan suatu proses. Agar bisa memimpin, pemimpin harus melakukan sesuatu.

3. Kepemimpinan harus membujuk orang orang lain untuk mengambil tindakan. Pemimpin membujuk pengikutnya melalui berbagai cara, seperti menggunakan otoritas yang terlegitimasi, menciptakan model (menjadi teladan), penetapan sasaran, memberi imbalan dan hukuman, restrukturisasi organisasi, dan mengkomunikasikan visi.

Sedangkan menurut Hayati (2002:47) mendefenisikan kepemimpinan sebagai proses mengarahkan dan mempengaruhi kegiatan yang berhubungan dengan tugas dari anggota kelompok. Ada tiga implikasi yang penting dari defenisi di atas yakni Pertama, kepemimpinan harus melibatkan orang lain, bawahan, atau pengikut. Kedua, kepemimpinan melibatkan distribusi yang tidak merata dari kekuasaan di antara pemimpin dan anggota kelompok. Ketiga, selain secara sah dapat mengarahkan bawahan atau pengikut mereka, pemimpin juga dapat mempunyai pengaruh.

Penelitian yang dilakukan oleh Eddie Raharja, Tahun 2010, dengan judul penelitianPengaruh Kompetensi

Kepemimpinan Dalam Pengorganisasian Kesiapsiagaan Dan Penggerakan Ketanggapdaruratan Bencana Terhadap Kinerja Petugas Pusat Penanggulangan Krisis Kesehatan Regional Sumatera Utara. Hasil penelitian menunjukkan bahwa kompetensi kepemimpinan nilai-nilai organisasi terhadap kinerja petugas, secara signifikan dan positif. Ada pengaruh kompetensi kepemimpinan keteladanan terhadap kinerja petugas, secara positif namun tidak signifikan. Ada pengaruh kompetensi kepemimpinan kerjasama tim terhadap kinerja petugas, secara tidak signifikan dan negatif. Ada pengaruh kompetensi kepemimpinan nilai-nilai organisasi terhadap kinerja petugas, secara signifikan dan positif. Ada pengaruh 
kompetensi kepemimpinan komunikasi terhadap kinerja petugas, secara signifikan dan positif. Kompetensi kepemimpinan siaga bencana mempunyai pengaruh siginifikan terhadap kinerja petugas PPK Kesehatan Regional Sumatera Utara.

\subsection{Analisis Pengaruh Kompetensi Aparatur terhadap Kualitas Pelayanan Publik}

Kompetensi aparatur berpengaruh terhadap kualitas pelayanan publik pada Badan Keluarga Berencana dan Pemberdayaan Perempuan Kota Banjar dengan kategori sedang. Hal ini menunjukkan bahwa Kompetensi aparatur berpengaruh sedang terhadap kualitas pelayanan public. Semakin baik Kompetensi aparatur maka akan semakin baik kualitas pelayanan publik pada Badan Keluarga Berencana dan Pemberdayaan Perempuan Kota Banjar.

Kompetensi menyangkut kewenangan setiap individu untuk melakukan tugas atau mengambil keputusan sesuai dengan peranannya dalam organisasi yang relevan dengan keahlian, pengetahuan, dan kemampuan yang dimiliki. Kompetensi yang dimiliki pegawai secara individual harus mampu mendukung pelaksanaan strategi organisasi dan mampu mendukung setiap perubahan yang dilakukan manajemen. Dengan kata lain, kompetensi yang dimiliki individu dapat mendukung sistem kerja berdasarkan tim (Rivai, 2009: 289). Dari kompetensi, kinerja atau kualitas pelayanan dihasilkan, kemudian dari kinerja atau kualitas pelayanan maka menghasilkan prestasi kerja dan terwujudnya efektivitas dan efisiensi. Sehingga jelas bahwa kompetensi yang merupakan variabel bebas dalam penelitian ini. Kompetensi pegawai merupakan faktor yang penting dan berpengaruh pada pelaksanaan dan penyelesaian pekerjaan-pekerjaan dalam suatu organisasi.

Kompetensi pegawai diartikan sebagai cara atau prosedur kerja yang benar yang dilakukan oleh para pegawai. Dengan demikian, untuk mewujudkan keberhasilan program-program yang telah ditetapkan oleh suatu organisasi, maka setiap pegawai didalamnya diharuskan memiliki standar kompetensi yang diperlukan. Menurut Becker (2011:156) mengemukakan bahwa kompetensi ditunjukkan dengan karakteristik individu yang terdiri dari pengetahuan, keterampilan, atau karakteristik kepribadian yang berpengaruh langsung terhadap kinerja. Menurut Lasmahadi (2011:45) kompetensi didefinisikan sebagai aspek-aspek pribadi dari seorang pekerja yang memungkinkan dia untuk mencapai kinerja yang superior. Aspek-aspek pribadi ini termasuk sifat, motif, sistem nilai, sikap, pengetahuan, dan keterampilan. Selanjutnya Spencer (2010:9) mengemukakan bahwa kompetensi adalah :

Karakteristik dasar seseorang atau individu yang berkaitan dengan efektivitas kinerja dan atau kinerja superior dalam suatu pekerjaan dan keadaan tertentu. Sebagai karakteristik dasar, kompetensi merupakan bagian dari kepribadian individu yang relatif dalam dan stabil, dapat dilihat dan diukur dari perilaku individu yang bersangkutan di tempat kerja atau dalam berbagai situasi.

Untuk itu kompetensi seseorang mengindikasikan kemampuan berperilaku seseorang dalam berbagai situasi yang cukup konsisten untuk suatu periode waktu yang cukup panjang dan bukan hal yang kebetulan semata. Kompetensi dapat digunakan untuk menduga atau terbukti secara empiris merupakan penyebab suatu keberhasilan perilaku atau kinerja yang secara akademis didasarkan pada kriteria ukuran keberhasilan sebagai standar kinerja yang dapat diterima secara bisnis maupun sosial. Kinerja organisasi jelas mencakup kinerja anggota organisasi. Karena itu kesuksesan kerja pada masing-masing anggota organisasi menjadi penting bagi tercapainya keberhasilan organisasi dalam 
mencapai tujuan-tujuan tertentu. Dalam konteks ini, McClelland (dalam Martin, 2012:151) mengatakan :Ada sesuatu karakteristik dasar yang lebih penting dalam memprediksikan kesuksesan kerja. Sesuatu itu, lebih berharga daripada kecerdasan akademik. Sesuatu itu dapat ditentukan dengan akurat, dapat menjadi titik penentu (critical factor) pembeda antara seorang star performer dan seorang dead wood. Menurut McClelland, sesuatu itulah yang disebut kompetensi.

Penelitian yang dilakukan Adianto Legowo Tahun 2000, dengan judul penelitian Evaluasi Kualitas Pelayanan Samsat dengan penerapan konsep Quality Fuction Deploymen (QFD) - Studi pada samsat Kota Yogyakarta. Penelitian ini berjudul untuk mengidentifikasi faktor pelayanan terhadap kepuasan wajib pajak. Penelitian ini mengidentifikasi penilaian kualitas pelayanan yang dikembangkan Parasuraman, Ziethani dan Bery (1998). Penilaian kualitas pelayanan dipandang sebagai tingkat dan arah perbedaan antara persepsi konsumen dan harapannya. Analisis yang digunakan adalah regresi linier berganda. Hasil penelitian menyimpulkan antara lain adalah secara parsial (uji t) faktor reliabilitas dan tangible masing-masing menjelaskan kepuasan wajib pajak, sedangkan secara bersamasama (uji F) kelima faktor yaitu reliability, responsiveness, assurance, emphaty, dan tangible berpengaruh pada wajib pajak.

\subsection{Analisis Pengaruh Kepemimpinan dan Kompetensi Aparatur terhadap Kualitas Pelayanan Publik}

Kepemimpinan dan kompetensi aparatur berpengaruh terhadap kualitas pelayanan publik dengan kategori sangat baik. Hal ini menunjukkan bahwa Kepemimpinan dan kompetensi aparatur berpengaruh sangat baik terhadap kualitas pelayanan publik. Semakin baik Kepemimpinan dan kompetensi aparatur maka akan semakin baik kualitas pelayanan publik. Baik itu orang yang bersifat komersial ataupun yang bersifat non komersial. Namun dalam pelaksanaannya terdapat perbedaan antara pelayanan yang dilakukan oleh orang yang bersifat komersial yang biasanya dikelola oleh pihak swasta dengan pelayanan yang dilaksanakan oleh organisasi non komersial yang biasanya adalah pemerintah.

Kegiatan pelayanan yang bersifat komersial melaksanakan kegiatan dengan berlandaskan mencari keuntungan, sedangkan kegiatan pelayanan yang bersifat non-komersial kegiatannya lebih tertuju pada pemberian layanan kepada masyarakat (layanan publik atau umum) yang sifatnya tidak mencari keuntungan akan tetapi berorientasikan kepada pengabdian.

Kegiatan pelayanan dalam suatu organisasi memiliki peran penting dan strategi, terutama bagi organisasi yang berorientasi pada pelayanan jasa. Hal itu tercermin pada pengertian pelayanan yang dikemukakan oleh Moenir (2000: 12) sebagai berikut : Pelayanan adalah setiap kegiatan oleh pihak lain yang ditujukan untuk memenuhi kepentingan orang banyak, pelayanan ini sifatnya selalu kolektif, sebab pelayanan kepentingan itu masih termasuk dalam rangka pemenuhan hak dan kebutuhan bersama yang telah diatur termasuk dalam pengertian pelayanan.

Sementara itu Sinambela (2008 : 5) memberikan pengertian pelayanan publik sebagai berikut: Setiap kegiatan yang dilakukan oleh pemerintah terhadap sejumlah manusia yang memiliki setiap kegiatan yang menguntungkan dalam suatu kumpulan atau kesatuan, dan menawarkan kepuasan meskipun hasilnya tidak terikat pda suatu produk secara fisik.

Adapun pengertian pelayanan publik menurut Kurniawan (2005 : 4) adalah: "Pemberian layanan (melayani) keperluan orang atau masyarakat yang mempunyai kepentingan pada organisasi itu sesuai 
dengan aturan pokok dan tatacara yang ditetapkan".

Menurut Undang-undang Nomor 25 Tahun 2009 tentang Pelayan Publik, mengatakan bahwa yang dimaksud dengan pelayanan publik adalah: Kegiatan atau ragkaian kegiatan dalam rangka pemenuhan kebutuhan pelayanan sesuai dengan peraturan perundang-undangan bagi setiap warga negara dan penduduk atas barang, jasa dan/atau pelayanan administratif yang disediakan oleh penyelenggara pelayanan publik.

Menurut Nugroho (2004 : 75) mengatakan bahwa: Tugas pelayanan publik adalah memberikan pelayanan, kepada umum tanpa membeda-bedakan dan diberikan secara Cuma-Cuma atau dengan biaya sedemikian rupa sehingga kelompok paling tidak mampu menjangkaunya.

Jadi dapat disimpulkan bahwa pelayanan publik adalah segala bentuk jasa pelayanan baik dalam bentuk barang publik maupun jasa publik yang pada prinsipnya menjadi tanggung jawab dan dilaksanakan oleh Instansi pemerintah di Pusat, di daerah, dan di lingkungan Badan Usaha Milik Negara atau Badan Usaha Milik Daerah, dalam rangka pelaksanaan ketentuan peraturan perundang-undangan.

\section{SIMPULAN}

Berdasarkan hasil penelitian dan pembahasan di atas, maka dapat disimpulkan beberapa hal sebagai berikut :

1. Kepemimpinan berpengaruh terhadap kualitas pelayanan publik pada Badan Keluarga Berencana dan Pemberdayaan Perempuan Kota Banjar dengan kategori sedang. Hal ini menunjukkan bahwa kepemimpinan berpengaruh positif terhadap kualitas pelayanan publik. Artinya semakin baik kepemimpinan maka akan semakin baik kualitas pelayanan publik.
2. Kompetensi aparatur berpengaruh terhadap kualitas pelayanan publik pada Badan Keluarga Berencana dan Pemberdayaan Perempuan Kota Banjar dengan kategori sedang. Hal ini menunjukkan bahwa Kompetensi aparatur berpengaruh positif terhadap kualitas pelayanan publik. Artinya semakin baik Kompetensi aparatur maka akan semakin baik kualitas pelayanan publik.

3. Kepemimpinan dan kompetensi aparatur berpengaruh terhadap kualitas pelayanan publik pada Badan Keluarga Berencana dan Pemberdayaan Perempuan Kota Banjar dengan kategori sangat baik. Hal ini menunjukkan bahwa Kepemimpinan dan kompetensi aparatur berpengaruh positif terhadap kualitas pelayanan publik. Artinya semakin baik kepemimpinan dan kompetensi aparatur maka akan semakin baik kualitas pelayanan publik.

\section{DAFTAR PUSTAKA}

Armstrong, Michael \& Baron A., (1998). Performance Management : The New Realities, institute of personal and development. New York.

Becker, (2011). The Open Ended Approach: a New Proposal for Teaching Mathematics. Virginia : NCTM.

Bubshait and Farooq, (2011). Auditor Cilent relationship and audit quality. New York.

Hayati, (2002). Manajemen Mutu Pendidikan. Bandung: Alfabeta

Herlina, E., Syarifudin, D., \& Mulyatini, N. (2018). Knowledge Transfer Dalam Konteks Spatial Creative Economy Untuk Mengurangi Kemiskinan Perdesaan di Kabupaten Ciamis. Jurnal Ekonologi Ilmu Manajemen, 5(1), 273-282. 
Hurriyati, Ratih, (2011). Bauran Pemasaran dan Loyalitas Konsumen. Cetakan pertama. Bandung : Alfabeta.

Kurniawan, Panca dan Purwanto, Agus, (2006). Pajak Daerah dan Retribusi Daerah di Indonesia. Malang: Banyumedia Publishing.

Lasmahadi, (2011). Mencapai Manajemen Berkualitas. Yogyakarta: Andi.

Martin, (2012). Some implementations of the boxplot. In: Computer Science and Statistics Proceedings of the 19th Symposium on the Interface, R. M. Heiberger, and M. Martin, eds. Alexandria, Virginia: American Statistical Association.

Nugroho, (2004). Negara, Pasar dan Keadilan Sosial. Yogyakarta: Pustaka Pelajar.

Rivai, (2009). Kepemimpinan dan Perilaku Organisasi. Jakarta : Rajawali Pers.

Sinambela, (2006). Reformasi Pelayanan Publik : Teori Kebijakan dan Implementasi. Cetakan kelima. Jakarta : PT. Bumi Aksara

Spencer, (2010). Competence at work: Models for Superior Performance. Canada : John Wiley \& Sons.

, Undang-undang No. 25 Tahun 2009 tentang Pelayanan Publik.

Peraturan Pemerintah Nomor 41 tahun 2007 tentang Pedoman Organisasi Perangkat Daerah

, UU Nomor 22 Tahun 1999 yang disempurnakan menjadi UU Nomor 32 Tahun 2004 tentang Pemerintahan Daerah dan UU Nomor 25 Tahun 1999 yang juga disempurnakan menjadi UU Nomor 33 Tahun 2004 Tentang Perimbangan Keuangan Antara Pemerintah Pusat dan Pemerintah Daerah 